\title{
Dóra Szendi
}

https://doi.org/10.32976/stratfuz.2021.38

\section{György Kocziszky (ed) (2021): Northern Hungary}

The Centre for Economic and Regional Studies of the Hungarian Academy of Sciences launched a series of monographs on the regions of the Carpathian Basin in 2003. This book series includes besides the introduction of the seven Hungarian regions, also the historical-natural-geographical, socio-economic conditions of the Zakarpatska Oblast (Kárpátalja), Southern Slovakia, Burgenland, Délvidék, Southern Transylvania and Banat, Székely Land and Vojvodina.

The authors of this monograph are analysing the situation of the statistical region of Northern Hungary as the final volume in the series (after Southern Transdanubia, Western Transdanubia, Central Hungary, Northern Great Plain, Southern Great Plain, Central Transdanubia).

Located in the north-eastern part of Hungary, the statistical region nowadays comprises three counties, Borsod-Abaúj-Zemplén, Heves and Nógrád, bordering Slovakia in the north, Central Hungary in the west, and the Northern Great Plain in the south and south-east, with the northsouth-eastern natural borderline of the Tisza. The region covers 13,433 km2, 14\% of the territory of Hungary. Borsod-Abaúj-Zemplén County accounts for $54 \%$ of the region's area, Heves County for $27 \%$ and Nógrád County for $19 \%$. The North-Hungarian Planning and Statistical Region was established under the Act XCII of 1999 in accordance with the European Union's territorial support and statistical analysis system (NUTS).

The monograph emphasize that $13 \%$ of the region's territory belongs to the protected areas of national and local importance, which is almost $22 \%$ of the total protected areas in Hungary. The administrative borders of the three counties, which were once part of the historical Felvidék, have been redrawn several times in the last 150 years, partly due to the Trianon diktat and partly due to the so-called administrative reforms. The region has a predominantly small and sparsely populated settlement structure, and its population has been monotonously decreasing since 1989 . A significant part of the book is dedicated to the historical and traditional development of the region, regarding industrial, economic policy, innovation, settlement structure history. Since the second half of the 19th century, the region's economy has been dominated by industry, mainly heavy industry (mining, metallurgy, heavy machinery). The favourable natural geographical conditions (ore, coal deposits, timber resources) has determined the direction of the region's technical and technological development, its manufacturing industry, its skills and employment structure, and its commercial and income conditions. The organic development and spatial structure of the economy was disrupted by the First and Second World Wars. It lost significant areas of its former raw material deposits, transport network and markets.

The region's economy was able to recover relatively quickly from the shock of the Trianon diktat, despite the fact that its raw material resources had been lost outside the new borders. By the mid-1920s, the region's GDP per capita had reached pre-war levels. The region's heavy industry and the technical and technological innovations made by industrial companies played a major role in this.

The post-World War II economic policy, which was based on the idea for a "country of iron and steel", led to serious imbalances and distortions in the structure of the economy. During the period of forced industrialisation, 18\% of national investment (1949-1968) came into the region, concentrated mainly in the Sajó valley, Gyöngyös, Kazincbarcika and Tiszaújváros.

Vocational and higher education in the region also served the development of heavy industry. The three technical faculties (Faculties of Earth Science and Engineering, of Materials Science and Engineering and of Mechanical Engineering) of the Miskolc Technical University for Heavy Industry (1949) provided the region's higher education workforce, with nearly $80 \%$ of graduates finding employment in the region. 
The short-lived attempt to introduce a new economic mechanism (1968-1971) did not bring any significant change in the economic and social composition of the region. This is underlined by the fact that even the Fourth Five-Year Plan (1971-1975) paid particular attention to the region's heavy industry. During this period, the continuous steel casting plant in Ózd, the stainless steel rolling mill at the Lenin Metallurgical Works, the reconstruction of the Salgótarján Metallurgical Works, the capacity improvement of the Gagarin Thermoelectric Power Plant (Gyöngyösvisonta), and the construction of the $750 \mathrm{kV}$ transmission line between the Tisza Thermoelectric Power Plant and the border of Hungary were put into operation. Cement plants with a capacity of 1070 tonnes were commissioned in Berente and 1600 tonnes in Hejöcsaba. During the same period, the second stage of the PVC plant of the Borsodi Vegyi Kombinát, the Olefin plant of Tiszai Vegyi Kombinát, with a capacity of 250,000 tonnes of ethylene and 125,000 tonnes of propylene per year, started to work.

However, the wasteful use of resources has worsened the region's productivity and economy. A significant proportion of investment in the national economy continued to be channelled into resource-inefficient heavy industries, and the political and economic leadership of the industrial region of Borsod and Nógrád continued to lobby for investment opportunities, with varying degrees of success.

Because of the distorted economic structure and low productivity, the region's economic situation has gradually deteriorated since the late 1970s. By the boom in the world oil prices, the extraction of the region's coal basis became increasingly unprofitable. The country's deteriorating equilibrium and currency shortages meant that the most necessary technical and technological developments were not carried out, which inevitably made the end products less competitive on the market. The vicious circle of declining value for money, deteriorating productivity and lack of development led the region into a recession that the economic policy was unable to address.

After the regime change, the low-processing level metallurgy, the one-sided mechanical engineering industry, which mainly supplied for Soviet exports, and the poorly structured construction, textile and food processing industries lost a significant part of their traditional markets. Most of the attempts at privatisation in the early 1990s and at attracting domestic and foreign capital proved unsuccessful. The efforts to restructure the region, which started in 1988, have changed direction more than once parallel with government cycles. Since the early 1990s, a number of concepts, strategies and programmes for regional, county and sub-regional development have been drawn up, but most of them have remained on the shelves of desks due to a lack of resources, commitment or elaboration.

Substantive changes to the region's economy and infrastructure began in the early $2000 \mathrm{~s}$. The M3 motorway was built and international component manufacturing companies moved into the region. The region's service sector started to develop. Its tourist capacity has expanded and enriched, new attractions have been created and the number of nights spent in the region has increased. The public and higher education sector has continued to develop. The historic Christian churches have played a major role in the renewal of public education in two waves (early 1990s and after 2000).

This promising process was interrupted by the 2008 financial crisis, but it gained momentum again after 2012. A number of tourism (e.g. Hollókő, Mezőkövesd-Zsóri, Miskolc-Tapolca, Diósgyör, Eger) and energy developments (e.g. Gyöngyös-Visonta) were carried out, and new production plants were created (e.g. Gyöngyös, Miskolc, Tiszaújváros, etc.). The cultural life of the region has been revitalised (e.g. Bartók Plus Opera Festival, CINEFEST Miskolc International Film Festival, Fesztiválkatlan, etc.).

In addition to the natural geography of the region, the monograph aims to provide an insight into the region's history, cultural history, demographic and religious composition, economic and social conditions, and changes in its spatial structure.

The final chapter aims to answer how far the positive social and economic processes that started in the region can be sustained. What will be the direction of the region's intelligent specialisation, can it provide the necessary skilled workforce, research and development 
infrastructure, to what extent and at what pace can the region's businesses integrate into the supply chain network and, last but not least, how will the region's population experience these changes? The editor of the monograph is György Kocziszky, professor emeritus at the University of Miskolc, Faculty of Economics, Institute of World and Regional Economics, and member of the Monetary Council of the Central Bank of Hungary. A sum of 37 authors have contributed to the creation of this monograph, which gives good insights into the regions development from the historical ages until nowadays. 